\title{
Variations in the Physico-Chemical Characteristics of Water in Five Peri- Urban Reservoirs in Kiambu and Nairobi City Counties, Kenya
}

\author{
Kitur Esther ${ }^{1}{ }^{*}$, Kiplagat Kotut ${ }^{2}$ and Kerich Richard ${ }^{1}$ \\ ${ }^{1}$ Department of Environmental Sciences, Kenyatta University, Nairobi, Kenya \\ 2University of Embu, Embu, Kenya
}

\begin{abstract}
Information on reservoirs is important as it forms a vital baseline for among others the detection of undesirable changes in water quality. Variations in the physicochemical characteristics of water were investigated in five peri-urban reservoirs Uhuru reservoir located in Nairobi City County and Ruiru, Ngewa, Comte and Kianjijibbe in Kiambu County between February 2014 and January 2015. The aim of the study was to establish the quality of water. Mean Secchi depth recorded in $\mathrm{cm}$ was $0.7 \pm 0.9$ in Uhuru, $0.9 \pm 0.43$ in Ruiru, $0.1 \pm 0.04$ in Ngewa, $0.1 \pm 0.6$ in Comte and $0.3 \pm 1.3$ in Kianjijibbe. Mean temperatures in ${ }^{\circ} \mathrm{C}$ were $23.8 \pm 1.8$ in Uhuru, $21.6 \pm 2.2$ in Ruiru, $24.3 \pm 2.9$ in Ngewa, $23.4 \pm 1.6$ in Comte and $24.0 \pm 1.9$ in Kianjijbbe. Electrical conductivity in $\mu \mathrm{S} \mathrm{cm}{ }^{-1}$ was $90.4 \pm 23.81$ in Uhuru, $45.8 \pm 5.7$ in Ruiru, $195.5 \pm$ 37.3 in Ngewa, $113.3 \pm 20.5$ in Comte and $298.94 \pm 41.5$ in Kianjjibbe. pH was 7.4 in Uhuru and Ruiru and 7.2, 7.3 and 7.7 in Ngewa, Comte and Kianjjibbe respectively. Dissolved oxygen in $\mathrm{mgL}^{-1}$ was $7.1 \pm 0.7$ in Uhuru, $7.1 \pm 0.26$ in Ruiru, $6.2 \pm 1.1$ in Ngewa, $7.6 \pm 1.1$ in Comte and $9.0 \pm 0.8$ in Kianjijibbe. Total alkalinity in mgL $\mathrm{CaCO}_{3}$ was $35.5 \pm 8.8$ in Uhuru, $18.0 \pm 0.24$ in Ruiru, $83.9 \pm 7.9$ in Ngewa, $41.1 \pm 8.9$ in Comte and $110.2 \pm 15.9$ in Kianjijibbe. Nitrate nitrogen $\mu g \mathrm{~L}^{-1}$ was $9.8 \pm 1.37 \mu \mathrm{g}$ $\mathrm{L}^{-1}$ in Uhuru, $9.0 \pm 12.5$ in Ruiru $4.2 \pm 0.43$ in Ngewa, $7.1 \pm 5.56$ in Comte and $13.6 \pm 1.14$ in Kianjijibbe. Total nitrogen in $\mu g \mathrm{~L}^{-1}$ was $33.1 \pm 22.7$ in Uhuru, $39.8 \pm 3.0$ in Ruiru, $34.1 \pm 22.5$ in Ngewa, $40.5 \pm 36.9$ and $32.5 \pm 28.7$ in Comte and Kianjijibbe reservoir respectively. Total phosphorus in $\mu g \mathrm{~L}^{-1}$ in the reservoirs was $0.8 \pm 0.14$ in Uhuru, $1.0 \pm 0.02$ in Ruiru, $1.0 \pm 0.77$ in Ngewa, $1.0 \pm 0.82$ in Comte and $2.7 \pm 0.25$ in Kianjjibbe. Soluble reactive silica in mgL ${ }^{-1}$ was $3.4 \pm 0.47$ in Uhuru, $4.0 \pm 0.64$ in Ruiru, $7.3 \pm 0.7$ in Ngewa, $5.9 \pm 0.15$ in Comte and $7.0 \pm 199$ in Kianijibe. Peak values of total nitrogen and total phosphorus were recorded during the wet season while high soluble reactive silica was recorded during the dry season. There was a significant difference in all measured physcio-chemical parameters between the reservoirs $(p<0.001, d f=59)$. The study concludes that the reservoirs investigated varied in levels of physico-chemical properties. The variation was attributed to differences in rainfall, volume of outflow and use dynamics of the water of the reservoir.
\end{abstract}

Keywords: Reservoir $\cdot$ Physcio-chemical parameters $•$ Water quality

\section{Introduction}

Water is a vital element among the natural resources [1]. It is critical for the survival of all living organisms including man, food production, economic development and as the sustenance of life on earth [1,2]. Globally, today many cities are faced with acute shortage of water, $40 \%$ of food supply is grown under irrigation and a variety of industrial processes depend on water [1]. The environment, economic growth and development are highly influenced by the quality of surface water and its seasonal availability [1]. According to WHO [3], the quality of drinking water is a powerful environmental determinant of health and therefore adequate supply of safe drinking water is universally recognized as a basic human need and a main source to fulfil diversified needs such as drinking, cooking, washing, irrigation, use in industries and farming [4]. Currently more than 1.2 billion people have no access to drinking water, 1.3 billion have inappropriate sanitary services, more than 200 diseases have been associated to contaminated water while about 6,000 people mostly children die daily from diarrhea diseases in peri-urban setups [5]. The quality of water is affected by human activities and Rivers Rwaka and Ithanji are main sources of water in the area has declined due to rise in urbanization, population growth, change in land use pattern and industrial production. Polluted water is a threat to human health and aquatic organisms $[1,5]$. Lack of water is considered as socio-economic obstructive factor of a country [3]. Many Communities in the world are increasingly turning to reservoir water for their needs.

Reservoirs are surface water bodies which are nourished by river bodies. Pollution of rivers is critical because of the inadequacy or non-existence of surface water quality protection measures and sanitation [1]. The wastes from human activities are disposed into rivers with little regards to their assimilative capacities and pollutants may go long distances before being diluted and may end up in the reservoirs thereby threatening food production, environment and human health. The quality of water is a function of either or both natural and human activities and the continued consumption of untreated or contaminated water is expected to pose short or long term health implications [1]. Therefore the evaluation of reservoir water quality is essential for the development of civilization and to establish database for future water resource strategic planning and development, management and conservation of water [6]. Studies on reservoir water have been conducted on hydroelectric power production reservoirs in Kenya but no comprehensive study has been conducted on reservoir in pre-urban areas where water is used for domestic purposes and for urban irrigation. In the study, the physicchemical parameters of water of pre-urban reservoirs were measured. A healthy aquatic ecosystem depends on the physic-chemical and biological

"Address for Correspondence: Kitur Esther, Department of Environmental Sciences, Kenyatta University, Nairobi, Kenya, Tel: 0722717101; E-mail: kitur.esther@ku.ac.ke, estherkitur2015@gmail.com

Copyright: $\odot 2020$ Esther K, et al. This is an open-access article distributed under the terms of the creative commons attribution license which permits unrestricted use, distribution and reproduction in any medium, provided the original author and source are credited.

Received: 07 February 2020; Accepted: 04 March 2020; Published: 11 March 2020 
contaminants of water [6]. The objectives of the study were to find out the variations in water quality parameters in the pre-urban reservoirs and whether the parameters vary with seasons.

\section{Materials and Methods}

\section{Study area}

The study area covers five reservoirs located in Nairobi city and Kiambu counties. Uhuru reservoir within Nairobi city county (commercial area), is located between latitude $36^{\circ} 57^{\prime} \mathrm{E}$ and $36^{\circ} 58^{\prime} \mathrm{E}$, longitude $1^{\circ} 58^{\prime} \mathrm{S}$ and $1^{\circ} 57^{\prime} \mathrm{S}$. It lies at an altitude of $1800 \mathrm{~m}$ above sea level and receives its water from Ngong River. Ruiru, Comte and Kianijibbe reservoirs are located in Kiambu County (an agricultural area). Ruiru reservoir lies between latitudes $1^{\circ} 85^{\prime} \mathrm{S}$, $1^{\circ} 85^{\prime} \mathrm{S}$ and longitudes $36^{\circ} 65^{\prime} 36^{\circ} 66^{\prime} \mathrm{E}$. It receives its water through Kimaiti, Ruiru, Ngeteti, and Gitindo rivers. Comte reservoir lies between latitude $1^{\circ} 76^{\prime} \mathrm{S}, 1^{\circ} 75^{\prime} \mathrm{S}$ and longitudes $36^{\circ}, 63^{\prime}$ and $36^{\circ} 64^{\prime} \mathrm{E}$ ' and Kianjijibbe lies between latitudes and $1^{\circ}, 76^{\prime} \mathrm{S}, 1^{\circ}, 75^{\prime} \mathrm{S}$ and longitudes $36^{\circ}, 63^{\prime} \mathrm{E}, 36^{\circ}, 64^{\prime} \mathrm{E}$. Comte and Kianjjibbe reservoirs receive their water through Kianjjibe river. Ngewa reservoir in Thika district within Kiambu county lies between latitudes $1^{\circ} 78^{\prime} \mathrm{S}, 1^{\circ}$, and $77^{\prime} \mathrm{S}$, longitudes $36^{\circ}, 65^{\prime} 36^{\circ} 66^{\prime} \mathrm{E}$. It receives its water through Gaia. Gaia has two tributaries, Ngewa and Choomba Rivers (Figure $1)$.

\section{Data collection and statistical data analysis}

Water samples were collected from the reservoirs for a period of one year. Water was collected from a depth of $20 \mathrm{~cm}$ using a water scooper. In Uhuru and Ruiru reservoirs water was collected from the centre of the reservoirs, this was possible with the use of a boat, in the other reservoirs where accessibility to the centre was not possible the water was collected near the dam wall away from the influence of the inflowing rivers. The water was transferred into $500 \mathrm{ml}$ plastic containers and transported to Kenyatta University environmental science laboratory for analysis. No preservatives were used as the water was analyzed within 24 hours. The physical parameters, electrical conductivity $(\mu \mathrm{S} \mathrm{cm}-1)$, temperature, dissolved oxygen were measured in the field using a conductivity probe (Type TetraCon 325) of a multiline meter (WTW, Weilheim-Germany) with automatic temperature compensation to $25^{\circ} \mathrm{C}$. Secchi depth was determined using a secchi disc [7]. In the laboratory, total alkalinity was determined titremetrically using $0.02 \mathrm{~N}$ standard $\mathrm{H}_{2} \mathrm{SO}_{4}$ and with mixed methyl red bromcresol indicator [7]. Nitrite nitrogen $\mathrm{NO}_{2}-\mathrm{N}$, total nitrogen (TN), orthophosphate phosphorus $\mathrm{PO}_{4}-\mathrm{P}$, total phosphate and soluble reactive silica (SRS) were determined colorimetrically using UV/VIS spectroscopy machine T80+ [7]. Data analysis was done using a computerized statistical programme (STATISTICA 8.0, 2007). The data was subjected to one way analysis of variance (ANOVA) and significant differences accepted at ( $p \leq 0.001$ ). Where significant difference was found, the mean valves were separated using posthoc Tukey's (HSD) test. Descriptive statistics for all collected data was also obtained using STATISTICA software.

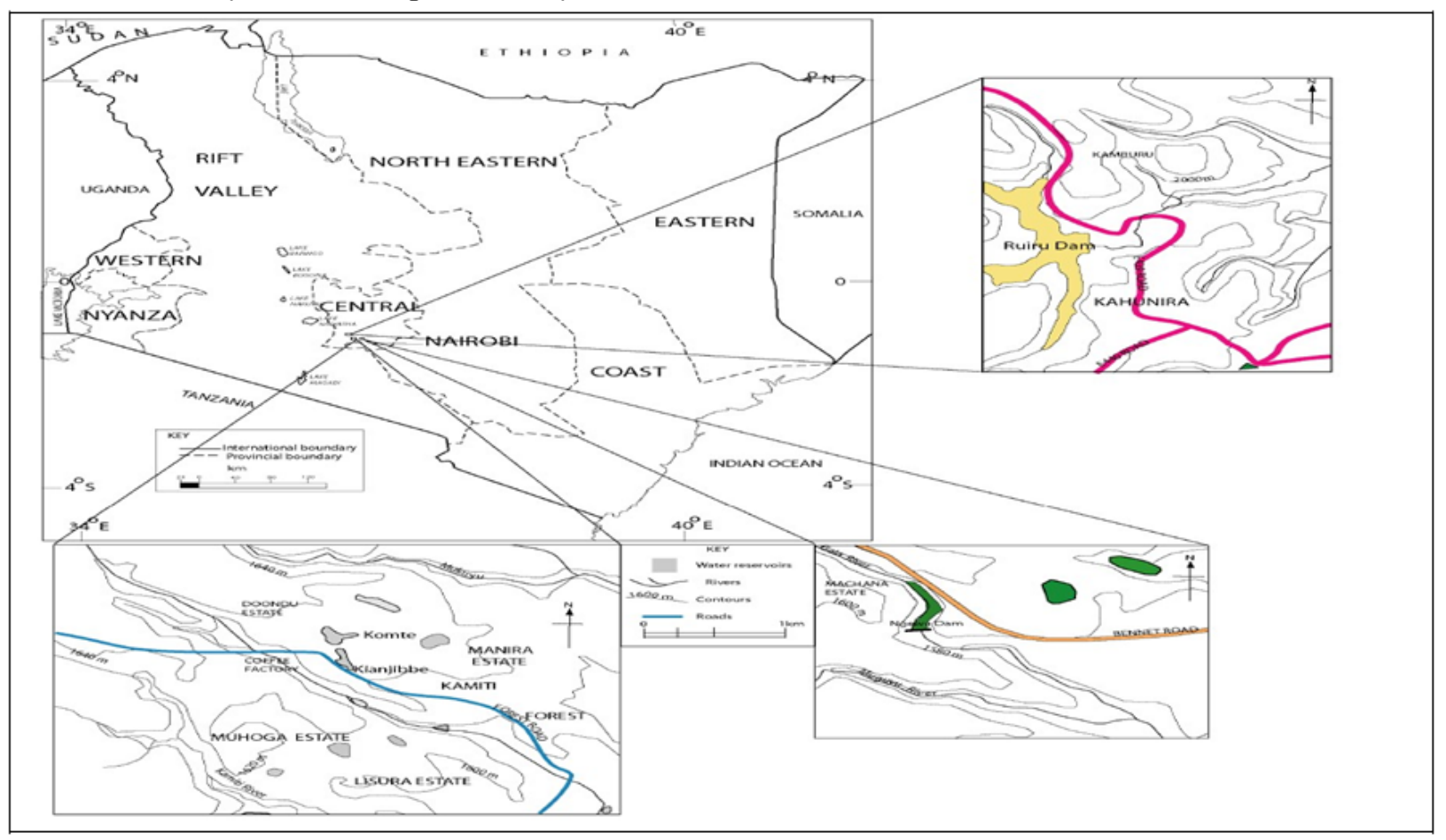

Figure 1. Map showing the location of Uhuru, Ruiru, Ngewa, Comte and Kianjijibbe reservoirs (Map drawn from the Map of Kenya, 2003).

\section{Results and Discussion}

The mean values of physico-chemical parameters measured in the five reservoirs are presented in Tables 1 and 2 respectively. There were significant variations $(p \leq 0.001)$ in all the physical and chemical parameters measured during the study period. Mean Secchi depth in $(\mathrm{cm})$ varied between $0.1 \pm 0.04$ in Ngewa, $0.1 \pm 0.6$ in Comte, and $0.3 \pm 0.13$ in Kianjijibbe, $0.7 \pm 0.9$ in Uhuru and $0.9 \pm 0.43$ in Ruiru (Table 1). One way ANOVA test showed mean Secchi depths were significantly different
$(P<0.000, d f=59)$. Mean separation using Tukey's test showed mean secchi depth in Ruiru and Uhuru were significantly different from each other and from the other reservoirs (Table 1). Secchi depth levels in reservoirs are influenced by increased discharge and runoff flood which bring in large amounts of suspended particles which reduce transparency. Water turbulence in shallow reservoir cause re-suspension of sediments from the bottom which increase turbidity [8,9]. The high mean Secchi depth at Ruiru reservoir $(0.9 \pm 0.43$ (Table 1 ) could be attributed to the greater depth of the reservoir which is approximately $17 \mathrm{~m}$ and its narrow and elongated shape that allows sediments to settle quickly, once settled, wind acting on reservoir 
surface cannot stir up the sediments. The shoreline of Ruiru reservoir also

has vegetation cover and this reduces shore erosion.

Table 1. Mean \pm standard deviation for physical parameters in Uhuru, Ruiru, Ngewa, Comte and Kianjijibbe reservoirs during the study period. Means in same row with different superscripts are significantly different at $p \leq 0.001$ levels.

\begin{tabular}{llllll}
\hline Parameters & Uhuru & Ruiru & Ngewa & Comte & Kianjijbbe \\
\hline Secchi depth & $0.7 \pm 0.9^{\mathrm{b}}$ & $0.9 \pm 0.43^{\mathrm{a}}$ & $0.1 \pm 0.04^{\mathrm{c}}$ & $0.1 \pm 0.6^{\mathrm{c}}$ & $0.3 \pm 0.13^{\mathrm{c}}$ \\
\hline Temperature $\left({ }^{\circ} \mathrm{C}\right)$ & $23.8 \pm 1.8^{\mathrm{c}}$ & $21.6 \pm 2.2^{\mathrm{c}}$ & $24.3 \pm 2.9^{\mathrm{b}}$ & $23.4 \pm 1.6^{\mathrm{a}}$ & $24.0 \pm 1.9^{\mathrm{c}}$ \\
\hline Cond. $\mu \mathrm{S} \mathrm{cm}-1$ & $90.4 \pm 23.8^{\mathrm{c}}$ & $45.8 \pm 5.7^{\mathrm{c}}$ & $195.5 \pm 37.3^{\mathrm{b}}$ & $113.3 \pm 20.9^{\mathrm{c}}$ & $298.9 \pm 41.5^{\mathrm{a}}$ \\
\hline pH & 7.4 & 7.4 & 7.2 & 7.3 & 7.7 \\
\hline $\mathrm{DO}\left(\mathrm{mgL}^{-1}\right)$ & $7.1 \pm 0.7^{\mathrm{c}}$ & $7.1 \pm 0.26^{\mathrm{c}}$ & $6.2 \pm 1.1^{\mathrm{c}}$ & $7.6 \pm 1.1^{\mathrm{b}}$ & $9.0 \pm 0.8^{\mathrm{a}}$ \\
\hline $\mathrm{TA}\left(\mathrm{mgL}^{-1}\right)$ & $35.5 \pm 8.8^{\mathrm{c}}$ & $18.0 \pm 0.24^{\mathrm{c}}$ & $83.9 \pm 7.9^{\mathrm{b}}$ & $41.1 \pm 8.9^{\mathrm{c}}$ & $110.2 \pm 15.9^{\mathrm{a}}$ \\
\hline
\end{tabular}

Temperatures in ${ }^{\circ} \mathrm{C}$ varied between $21.6 \pm 2.2$ in Ruiru, $23.4 \pm 1.6$ in Comte, $23.8 \pm 1.8$ in Uhuru, $24.0 \pm 1.9$ in Kiajjibbe and $24.3 \pm 2.9$ in Ngewa reservoir (Table 1). One way ANOVA revealed mean temperatures between the reservoirs were significantly different $(P<0.02, d f=59)$. Mean separation using Tukey's test showed Ngewa and Ruiru reservoirs were significantly different from each other and from other reservoirs (Table 1). Water surface temperature is influenced by several factors. According to Breen et al. [10], surface water temperature follows the ambient air temperature closely. A low mean water temperature at Ruiru reservoir of $21.6^{\circ} \mathrm{C}$ (Table 1) could be attributed to the location of the reservoir at a high altitude of about $1850 \mathrm{~m}$ above sea level and also the river inflow into the reservoir is from higher altitudes with cooler temperatures (1980 $\mathrm{m}$ to $2000 \mathrm{~m}$ above sea level). On the other hand, a high mean temperature of $24.3^{\circ} \mathrm{C}$ in Ngewa (Table, 1) could be due to the fact that Ngewa is located at a lower altitude of $1600 \mathrm{~m}$ above sea level. It was observed that Ngewa reservoir receives limited inflows mostly in the form of surface run-off and therefore has a limited outflow hence there is progressive warming of the water.

Electrical conductivity in $\mu \mathrm{S} \mathrm{cm}^{-1}$ varied between $45.8 \pm 5.71$ in Ruiru, $90.4 \pm 23.8$ in Uhuru, $113.4 \pm 20.54$ in Comte, $195.5 \pm 37.3$ in Ngewa and $298.9 \pm 41.5$ in Kianjijibbe (Table 1). One way ANOVA test showed that the mean conductivity values between the reservoirs were significantly different $(P<0.001, d f=59)$. Mean separation using Tukey's test revealed that Kianjijibbe and Ngewa reservoirs were significantly different from each other and from other reservoirs investigated (Table 1). Reservoir water conductivity is influenced by variation of total dissolved solids in the inflowing water and water residence time in the reservoir [11]. In tropical waters, marked seasonal variation in temperature and rainfall influences the conductivity of water bodies [12], lowland cultivated areas have more total solids than highland cultivated areas [13]. A high mean conductivity at Kianjjibbe reservoir (Table 1) possibly resulted from a number of factors that include the location of the reservoir in a rich agricultural area with different human activities. Since its main source of water is surface run-off, after the rains, a large amount of total dissolved solids is carried into the reservoir. The reservoir is also situated at a lower altitude and as such receives a rich inflow of dissolved solids. Since its water is retained for irrigation during the dry season, the reservoir has a longer residence. This coupled with the high temperatures at low altitudes (800 $\mathrm{m}$ above seas level) results in greater evaporative concentration. Water at the Ruiru reservoir is mainly used to provide municipal water and hence the water has a short residence time. Ruiru reservoir also receives water from high altitudes (above $1850 \mathrm{~m} \mathrm{ASL}$ ) with cooler temperatures and therefore limited evaporation. The large volume of discharge from Ruriu, Ngeteti, Rungiki and Gitindo rivers brings about reservoir dilution and therefore low conductivity in Ruiru Reservoir.
The median $\mathrm{pH}$ values recorded for the reservoir was 7.4, 7.4, 7.2, 7.3 and 7.7 for Uhuru, Ruiru, Ngewa, Comte and Kianjijibbe respectively (Table 1). Under natural conditions $\mathrm{pH}$ is dependent on the amount of carbonate and bicarbonate alkalinity and carbon dioxide in solution [14]. The balance between photosynthesis, respiration (decomposition) and the buffered state of reservoir determines $\mathrm{pH}$ in an aquatic ecosystem. The variations in $\mathrm{pH}$ ranges recorded at the reservoirs during the study period could be attributed to difference in time of sampling and ambient conditions at the reservoirs at the time of sampling. Sampling was done between $9 \mathrm{am}$ and $4 \mathrm{pm}$ and the ambient conditions varied from a clear sky to $100 \%$ cloudy. On clear days photosynthetic rate increases rapidly after sunrise and remain high until almost sundown [15].

Cloudy skies cause a decrease in photosynthetic rates [16]. A high median pH at Kianjijibbe reservoir (Table 1) can be attributed to the time of sampling, Kianjjibbe reservoir was sampled between 12 noon and $4 \mathrm{pm}$, a time when the rate of photosynthesis was high. The high phytoplankton biomass could have contributed to the high rate of photosynthesis at the reservoir. The removal of $\mathrm{CO}_{2}$ during algal photosynthesis raises the $\mathrm{pH}$ of the reservoir. Similarly at the time of sampling the sky was clear with cloud cover rarely exceeding $10 \%$. The lower $\mathrm{pH}$ at Ngewa and Comte possibly resulted from the time of sampling. The reservoirs were sampled between 9 am and 12 noon a time when the rate of photosynthesis had not picked up. High temperatures at the reservoirs could have brought higher rates of decomposition and hence higher levels of carbon dioxide.

Dissolved oxygen concentration in $\mathrm{mgL}^{-1}$ varied between $6.2 \pm 1.09$ in Comte, $7.0 \pm 0.26$ in Ruiru, $7.1 \pm 0.75$ in Uhuru, $7.6 \pm 1.08$ in Ngewa, and $9.0 \pm 0.8$ in Kianijibbe (Table 1). Using one way ANOVA, the mean dissolved oxygen concentrations at the reservoirs investigated were significantly different $(P<0.001, d f=59)$. Mean separation using Tukey's test revealed that Kianjijibbe and Comte reservoirs were significantly different from each other and from the other reservoirs (Table 1). Variations in dissolved oxygen recorded within and between the reservoirs can be attributed to variations in sampling time and the ambient conditions at the reservoirs at the time of sampling. Ambient conditions e.g., cloud cover, influences the rate of photosynthesis. Low levels of DO are characteristic of cloudy days when the rate of photosynthesis is low. Phytoplankton abundance also influences the rate of photosynthesis [15]. High mean DO values at Kianjjibbe reservoir (Table 1) could be attributed to the time of sampling as well as the phytoplankton abundance. Kianjjibbe reservoir was sampled between 12 noon and $1 \mathrm{pm}$ a time when the rate of photosynthesis was high leading to a net accumulation of DO in water, also on most sampling dates the sky was clear with less than $10 \%$ cloud cover. Low mean dissolved oxygen at Ngewa (Table 1) is due to its shallow depth and the higher temperatures recorded which favour the decomposition of organic matter. 
Total alkalinity in $\mathrm{mgL}^{-1} \mathrm{CaCO}_{3}$ varied from $18.0 \pm 0.24$ in Ruiru, $35.3 \pm$ 8.76 in Uhuru, $41.1 \pm 8.92$ in Comte, $83.9 \pm 7.88$ in Ngewa and $110.5 \pm 15.9$ in Kianjijibbe (Table 1). Using one way ANOVA test, mean total alkalinity values of the reservoirs were significantly different $(P<0.001, d f=59)$. Mean separation using Tukey's test revealed that Kianjijibbe and Ngewa reservoirs were significantly different from each other and from other reservoirs (Table 1). Total alkalinity is determined by the equilibrium between carbon dioxide, bicarbonates and carbonates, and any variation is caused by internal generation of alkalinity (photosynthesis and respiration), watershed weathering processes. In general, a greater rock weathering combined with increased evaporative concentration brings about a high alkalinity (14). The low mean total alkalinity at Ruiru reservoir (Table 1) could be explained by the high discharge from the inflowing rivers (Ruiru, Kimaiti, Ngeteti, Rungiki and Gitindo). The low overall temperatures (Table 1) also contribute to low evapotranspiration at the reservoir. Absence of an outlet and reliance on runoff may have contributed to a high mean total alkalinity (Table 1) at Kianjjibbe reservoir. In the absence of an outlet evaporation makes an important contribution to water loss from the reservoir. The water collected at the reservoir is retained to be used for irrigation during the dry season. This increases the length of time the water is in contact with the parent rock thus resulting in a greater rock weathering.

\section{Chemical parameters}

Nitrate-nitrogen $\left(\mathrm{NO}_{3}-\mathrm{N}\right)$ values varied from between $4.2 \pm 0.43 \mu \mathrm{gL}^{-1}$ in Ngewa, $7.1 \pm 5.56 \mu \mathrm{gL}^{-1}$ in Comte, $9.0 \pm 12.5 \mu \mathrm{gL}^{-1}$ in Ruiru, $9.8 \pm 1.37$ $\mu \mathrm{gL}^{-1}$ in Uhuru and $13.656 \mu \mathrm{gL}^{-1}$ Kianjjibbe reservoir (Table 2). Using one way ANOVA test, mean nitrate nitrogen values between the reservoirs were significantly different $(P<0.001, d f=59)$. Mean separation using Tukey's test revealed that Kianjjibbe and Uhuru reservoirs were significantly different from each other and from the other reservoirs investigated (Table 2). Total nitrogen in the reservoirs showed variations from between $32.5 \pm 28.7 \mu \mathrm{gL}^{-1}$ in Kianjijibbe, $33.1 \pm 22.7 \mu \mathrm{gL}^{-1}$ in Uhuru, $34.1 \pm 22.5 \mathrm{\mu gL}^{-1}$ in Ngewa, $40.5 \pm$ $22.5 \mu \mathrm{gL}^{-1}$ in Comte and $39.8 \pm 3.0 \mu \mathrm{gL}^{-1}$ in Ruiru reservoir. Using one way ANOVA test, mean total nitrogen values for the reservoirs investigated were significantly different $(P<0.5, d f=59)$. Mean separation using Tukey's test revealed that Comte and Ruiru reservoirs were significantly different from each other (Table 2).

High total nitrogen values in all the reservoirs during the wet season can be attributed to the high load of organic matter in floodwater from adjacent catchment through run-off and river input. When the river flow resumes after the dry season, the dry season accumulation of portable organic and inorganic matter on the dried river bed and the catchments area is swept downstream by the first floodwater and this contributes to high values of nitrogen The agricultural activities which use inorganic and organic fertilizers and commercial/industrial activities around the catchments also contribute to the high levels of total nitrogen. Although total nitrogen in inflow was not measured, it is likely that an important source of nitrogen is the organic matter load through inlets. Direct organic matters from settlements, agricultural and industrial/commercial activities make a significant impact on levels of total nitrogen at the reservoirs [17-19]. The high nitrogen levels in reservoirs could also be due to increased biological activities during the wet season. At Ngewa reservoir, low mean total nitrogen (Table 2) could be explained by the small size of catchment. Small catchments have low levels of total nitrogen as the run-off water has short distance to gather nutrients before it reaches the reservoir. Similarly, the presence of a fringing vegetation zone helps reservoirs filter the run- off before it gets into the reservoir. This contributed to lower levels of TN in some reservoirs. High mean total nitrogen values at Kianjijibbe reservoir (Table 2) can be attributed to its large catchment area as well as the intense agricultural activities at the catchment. Kianjijibbe reservoir receives surface run-off from a very large catchment's area, about $16,000 \mathrm{~km}^{2}$ and therefore rainfall and surface run-off has a long time to gather the nutrients before it gets to the reservoir. Intense agriculture with the use of organic and inorganic fertilizers contribute high amount of nitrogen to the reservoir. Higher temperatures as a result of the lower altitude (1600 m above sea level) possibly promote faster decomposition of organic matter at the reservoir. The reservoir also lacks a fringing shore vegetation cover hence during flood periods most of the flood water ends up in the reservoir. High levels of total nitrogen have the potential of causing frequent blooms of toxic cyanobacteria [20].

Total phosphorus recorded was between $0.7 \pm 0.25 \mu \mathrm{gL}^{-1}$ Kianjjibbe $\mu \mathrm{gL}^{-1}, 0.8 \pm 0.14 \mathrm{\mu g}^{-1}$ in Uhuru, $1.0 \pm 0.01 \mu \mathrm{gL}^{-1}$, Ruiru, $1.0 \pm 0.77 \mu \mathrm{gL}^{-1}$, in Ngewa, $1.0 \pm 0.08 \mu \mathrm{gL}^{-1}$ Comte (Table 2). Using the one way ANOVA test, mean total phosphorus values for the reservoirs investigated were significantly different $(P>0.001, d f=59)$. Mean separation using Tukey's test showed that Uhuru and Kianjijibbe were significantly different from each other and from the other reservoirs (Table 2). Variations in total phosphorus concentration in reservoirs can be attributed to differences in anthropogenic activities, domestic and industrial inputs of phosphorus such as sewage disposal and soluble polydetergents [11,21-23], rainfall frequency and vegetation type at the catchments [24,25]. In general a low phosphorus concentration in freshwater reservoirs is characteristics of areas with low rainfall intensity and well developed vegetation cover [26]. The high total phosphorus concentration recorded in Ngewa reservoir (Table 2) could be attributed to the fact that Ngewa is within a coffee plantation and receives run-off from farms, which use fertilizers, it may also be due to the introduction of detergent rich effluents as the water is used for bathing and washing clothes. Low levels of total phosphorus recorded at Uhuru reservoir can be attributed to the fact that Uhuru is far away from the agricultural farms and also receives water from an underground drain.

Soluble reactive silica recorded in Uhuru and Ruiru reservoirs were $3.4 \pm$ $0.47 \mathrm{mgL}^{-1}$ and $4.01 \pm 0.64 \mathrm{mgL}^{-1}$ respectively, $5.9 \pm 0.15 \mathrm{mgL}^{-1}$ in Comte, $7.0 \pm 1.99 \mathrm{mgL}^{-1}$ in Kianjjibbe and $7.3 \pm 0.74 \mathrm{mgL}^{-1}$ in Ngewa (Table 2). A one way ANOVA test established that SRS values at the reservoirs investigated were significantly different $(P<0.05, d f=59)$. Mean separation using Tukey's test revealed that Ngewa and Kianjjibbe reservoirs were significantly different from each other and from the other reservoirs investigated (Table 2). Soluble reactive silica (SRS) in reservoirs is derived from the weathering of silica rocks under the influence of carbon dioxide [27]. Variation in SRS soluble in reservoirs is dependent on the rate of weathering [14]. The high concentration of soluble reactive silica at Ruiru (Table 2) can be attributed to the large volume of inflow into the reservoir and the geochemistry of the catchment area. Ruiru catchment area has a number of quarries some of which have been abandoned.

Table 2. Mean \pm standard deviation for chemical parameters in Uhuru, Ruiru, Ngewa, Comte and Kianjijbbe reservoirs during the study period. ${ }^{a, b, c, d}$ Means in same row with different superscripts are significantly different at $p \leq 0.001$ levels.

\begin{tabular}{llllll}
\hline Parameters & Uhuru & Ruiru & Ngewa & Comte & Kianjijibbe \\
\hline $\mathrm{NO}_{3}-\mathrm{N}\left(\mu \mathrm{gL}^{-1}\right)$ & $9.8 \pm 1.37^{\mathrm{b}}$ & $9.0 \pm 12.5^{\mathrm{c}}$ & $4.2 \pm 0.43^{\mathrm{c}}$ & $7.1 \pm 5.56^{\mathrm{c}}$ & $13.6 \pm 1.14^{\mathrm{a}}$ \\
\hline $\mathrm{TN}\left(\mu g \mathrm{~L}^{-1}\right)$ & $33.1 \pm 22.7^{\mathrm{c}}$ & $39.8 \pm 3.0^{\mathrm{b}}$ & $34.1 \pm 22.5^{\mathrm{c}}$ & $40.5 \pm 36.9^{\mathrm{a}}$ & $32.5 \pm 28.7$ \\
\hline
\end{tabular}




\begin{tabular}{|c|c|c|c|c|c|}
\hline $\mathrm{TP}\left(\mu g \mathrm{~L}^{-1}\right)$ & $0.8 \pm 0.14^{b}$ & $1.0 \pm 0.02^{\mathrm{a}}$ & $1.0 \pm 0.77^{a}$ & $1.0 \pm 0.82^{\mathrm{a}}$ & $0.7 \pm 0.25^{c}$ \\
\hline $\operatorname{SRS}\left(\mathrm{mgL}^{-1}\right)$ & $3.4 \pm 0.47^{c}$ & $4.0 \pm 0.64^{c}$ & $7.3 \pm 0.74^{\mathrm{a}}$ & $5.9 \pm 0.15^{c}$ & $7.0 \pm 199^{b}$ \\
\hline
\end{tabular}

\section{Conclusion and Recommendations}

The study revealed variations in the physic-chemical parameters of water in the peri-urban reservoirs. There is a clear sign of the impacts of anthropogenic activities within the reservoirs and the impacts of the anthropogenic activities on the quality of water vary with seasons. Therefore it is concluded that good farming practices around the reservoir catchment and regular monitoring of water quality is highly recommended.

\section{Acknowledgements}

I give special thanks to Managing Director SOCFINAF Company Ltd and Director Water and Sewerage Department of Nairobi County Council and the staff for granting me access to the reservoirs, their co-operation and assistance during sample collection. Special thanks to Mr. Mwangi of the Department of Plant and Microbial Science, Kenyatta University both in the field and in the laboratory.

\section{References}

1. Halder, Joshua Nizel, and Nazrul Islam. "Water pollution and its impact on the human health." J Environ Human 2 (2015): 36-46.

2. Nahyan AL. Keynote address. World Future Energy Summit 2012. Abu Dhabi, UAE. 2012.

3. World Health Organization and Stop TB Initiative (WHO). "Treatment of tuberculosis: Guidelines." World Health Organization. 2010.

4. Rim-Rukeh, Akpofure, Grace Ikhifa, and Peter Okokoyo. "Physico-chemical characteristics of some waters used for drinking and domestic purposes in the Niger Delta, Nigeria." Environ Monitoring and Assessment 128 (2007): 475-482.

5. Edition, Fourth. "Guidelines for drinking-water quality." WHO Chronicle 38 (2011): $104-8$

6. Heubel, Katja, and Ingo Schlupp. "Turbidity affects association behaviour in male Poecilia latipinna." J Fish Bio/68 (2006): 555-568.

7. Federation, Water Environmental, and American Public Health Association. "Standard methods for the examination of water and wastewater." American Public Health Association (APHA): Washington, DC, USA (2005).

8. Brönmark, Christer, and Lars-Anders Hansson. The biology of lakes and ponds. Oxford University Press, (2017).

9. Walmsley, Rd, and Ca Bruwer. "Water transparency characteristics of South African impoundments." J Limnol Society Southern Africa 6 (1980): 69-76.

10. Symoens, Jean-Jacques, Mary Burgis, and John Gaudet. "The ecology and utilization of African inland waters." (1981).

11. Ansa, Sare. A comparative study of nutrients status of the lakes in southeastern Ghana. In: Lakes, Reservoirs, Res Manag. (2000).

12. Chapman, Deborah. "Water quality assessments: A guide to the use of biota, sediments, and water in environmental monitoring." (1996).
13. Maitland, Peter. Biology of fresh waters. Springer Science $\varepsilon$ Business Media. (2013).

14. Talling, Jif, and Ida Talling. "The chemical composition of African lake waters." International Revue der gesamten Hydrobiologie und Hydrographie. 50 (1965): 421-463.

15. Heris, Geni, Piccinin Bean, and Ryn Jin. Physiological and environmental constraints in the ecology of the planktonic dinoflgellates Ceratium hirundinella. Archiv Hydrobiol. 98 (1983):215-39.

16. Romaire, Robert and Claude Boyd. "Effects of solar radiation on the dynamics of dissolved oxygen in channel catfish ponds." Transactions of the American Fisheries Society. 108 (1979): 473-478.

17. Tebbutt, Thomas and Hugh Yelland. Principles of water quality control. Elsevier. (1997).

18. Purwanto, Edi. "Erosion, sediment delivery and soil conservation in an upland agricultural catchment in West Java, Indonesia." (1999).

19. Van Dijk, Albert Ide Jan Martijn. Water and sediment dynamics in benchterraced agricultural steeplands in West Java, Indonesia. AlJM van Dijk. (2002).

20. Oberholster, Ping, Am Botha, and Tie Cloete. "Toxic cyanobacterial blooms in a shallow, artificially mixed urban lake in Colorado, USA." Lakes $\varepsilon$ Reservoirs: Res Manag. 11 (2006): 111-123.

21. Gleick, Ph, Singh Amit and Shi, Hean. Threats to the world freshwater reservoirs. Pacific institute and UNEP, California, USA. (2001).

22. Bartram, Jamie, and Richard Ballance. Water quality monitoring: A practical guide to the design and implementation of freshwater quality studies and monitoring programmes. CRC Press, (1996).

23. Chapman, Lauren, and Donald Kramer. "Limnological observations of an intermittent tropical dry forest stream." Hydrobiologia. 226 (1991): 153-166.

24. Viner, Am. "The supply of minerals to tropical rivers and lakes (Uganda)." In: Coupling of land and water systems, pp. 227-261. Springer, Berlin, Heidelberg, (1975).

25. Meybeck, Michel, Lin Laroche, Hans Dürr, and James Syvitski. "Global variability of daily total suspended solids and their fluxes in rivers." Global and Planetary Change. 39 (2003): 65-93.

26. Rijsdijk, Anton, LA Sampurno Bruijnzeel, and Thm Prins. "Sediment yield from gullies, riparian mass wasting and bank erosion in the Upper Konto catchment, East Java, Indonesia." Geomorpho/87 (2007): 38-52.

27. Hutchinson, Evelyn. "Limnological studies in Connecticut. VII. A critical examination of the supposed relationship between phytoplakton periodicity and chemical changes in lake waters." Ecology. 25 (1944): 3-26.

How to cite this article: Kitur Esther, Kotut Kiplagat and Richard Kerich. "Variations in the Physico-Chemical Characteristics of Water in Five PeriUrban Reservoirs in Kiambu and Nairobi City Counties, Kenya". J Environ Anal Chem 7 (2020) doi: 10.37421/jreac.2020.7.264 